Z. klin. Chem. u. klin. Biochem.

8. Jg., S. $311-313$, Mai 1970

\title{
Zur Frage von Antigenbeziehungen des C-reaktiven Proteins zu normalen Lipoproteiden und zur $\beta_{1} \mathrm{c}-$ Fraktion
}

\author{
Von Hilde Götz und F. Scheiffarth \\ Abteilung für klinische Immunologie des Universitätskrankenhauses Erlangen-Nürnberg \\ (Vorstand: Prof. Dr. F. Scheiffarth) \\ (Eingegangen am 15. Januar 1970)
}

Vergleichende immunchemische Analysen der Immunpräzipitate von C-reaktivem Protein jeweils mit $\alpha_{1}$-Lipoproteid, $\alpha_{2}$-Lipoproteid, $\beta_{1}$-Lipoproteid sowie mit $\beta_{1 \mathrm{C}}$-Globulin, haben ergeben, daß C-reaktives Protein mit keiner der genannten Scrumfraktionen eine Antigenverwandtschaft aufweist.

\section{The question of antigenic relationships between $C$-reactive protein and normal lipoproteins and $\beta_{1 \mathrm{c}}$-protein}

Comparative immunochemical analyses of immunoprecipitates of C-reactive protein with each of $\alpha_{1}$-lipoprotein, $\alpha_{2}$-lipoprotein, $\beta_{1}$-lipoprotein as well as with $\beta_{1 \mathrm{c}}$-protein have shown that none of these serum fractions possesses antigenic relationship to $C$-reactive protein.

Im Präzipitatmuster eines immunelektrophoretisch differenzierten CRP-positiven Serums findet sich bei Verwendung eines polyvalenten Antihumanserums das C-reaktive Protein (CRP) als langgestreckte, zumeist scharf gezeichnete Linie im Bereich des $\gamma$-Immunglobulin-Systems (Abb. 1); diese Linie verläuft nahezu

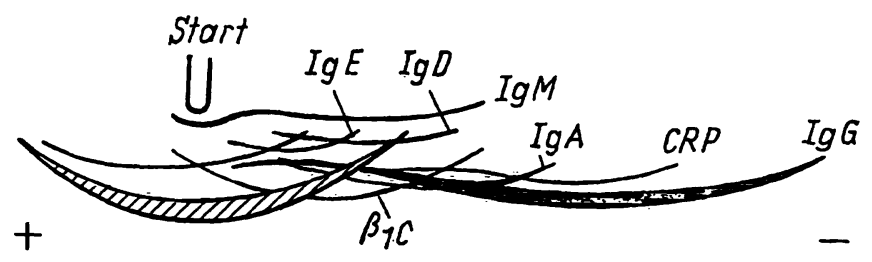

Abb. 1

Halbschematische Darstellung der Präzipitate des $\beta / \gamma$-Globulin-Systems eines immunoelektrophoretisch differenzierten menschlichen Serums. $\mathrm{CRP}=\mathrm{C}$-reaktives Protein

parallel zum IgG-Präzipitatbogen; sie weist keinerlei partielle oder totale immunologische Identitätsreaktionen mit benachbarten $\beta$ - oder $\gamma$-Fraktionen auf (1-15).

In der einschlägigen Literatur wird, dessen ungeachtet, immer wieder auf Assoziierungsphänomene des C-reaktiven Proteins mit Lipoiden des menschlichen und experimentell gewonnenen C-reaktiven Proteins des $\mathrm{Ka}$ ninchens mit entsprechenden Lipoiden hingewiesen (14, 16-19), ohne daß diese Frage bis heute neu aufgegriffen und völlig geklärt worden. wäte. Außerdem ist bekannt, daß C-reaktives Protein bei der spezifischen CRP-Anti-CRP-Reaktion Komplement bindet, worauf die in der älteren Immunologie angewandte Komplementbindungsreaktion zur quantitativen $\mathrm{Be}$ stimmung des C-reaktiven Proteins gegründet war (in $18,20,21)$. Von anderer Seite wurde allerdings festgestellt, daß weder zur Präzipitation von C-Polysaccharid und C-reaktivem Protein noch zur Präzipitation von C-reaktivem Protein und spezifischem Anti-CRP Komplement erforderlich ist (in 18). Hier interessiert, ob be- reits antigene Beziehungen zwischen C-reaktivem Protein und dem - elektrophoretisch - benachbarten $\beta_{1 c^{-}}$Protein $^{1}$ ) bestehen.

Zur Klärung dieser Fragen wurden nachfolgend beschriebene, vergleichende immunchemische Analysen vorgenommen.

\section{Untersuchungsgut, Versuchungsordnung und Methodik}

Untersuchungsgut

Es wurden 24 CRP-positive Seren, die mit der üblichen AntiCRP-Latex-Technik für CRP-positiv befunden wurden, darunter 4 stark lipämische Seren, untersucht. Die Seren stammten von Patienten mit primär-chronischer Polyarthritis (mit akuten Schüben), asthmoider Bronchitis, Hepatitis epidemica sowie von zwei Patienten mit $\gamma$ G-Myelom.

Versuchsanordnung

Die verschiedenen Seren wurden mit Hilfe der zweidimensionalen Immuno-Doppeldiffusion im Agargel unter Verwendung monovalenter Antiseren gegen $\alpha_{1}$-Lipoproteid, $\alpha_{2}$-Lipoproteid, $\beta_{1}$ Lipoproteid sowie $\beta_{1 \mathrm{c}}$-Protein mit nachfolgender Lipoproteidfärbung analysiert. Dabei wurde die Anordnung von Serum- und Antiserumproben so getroffen, daß das spezifische CRP-AntiCRP-Präzipitat jeweils mit dem Präzipitat einer der für die vergleichenden Analysen gewählten Serumfraktionen in unmittelbare Beziehung gebracht werden konnte (vgl. Abb. 2).

Methodik

Blutentnabmse

Die Blutentnahmen erfolgten beim nüchternen Patienten lege artis durch Punktion einer Armvene unter sterilen Kautelen. Die erwähnten stark lipämischen Seren ergaben sich aufgrund einer pathologischen Hyperlipämie, nicht alimentär.

\section{Zneidimensionale Immuno-Doppeldiffusion im Agargel}

Es wurde nach der von OuchiterLoNy (22) beschriebenen Technik vorgegangen. Es wurde cin 1proz. gepufferter ${ }^{2}$ ) Agar verwendet.

1) $\beta_{1 \mathrm{c}}$ entspricht det hydrazinempfindlichen $C^{\prime} 3 \mathrm{a}-$ Komponente des Komplementfaktors $C^{\prime} 3$ eines menschlichen Serums.

2) Phosphat-Puffer $\mathrm{pH} 7,1(0,15 \mathrm{M})$. 
Die Scrumproben wurden jeweils in normaler Konzentration, die verschiedenen Antiseren gegen $\alpha_{1}-\alpha_{2}$ - und $\beta_{1}$-Lipoproteid sowie gegen $\beta_{1 \mathrm{c}}$-Protein ebenfalls in normaler, $d . h$. in der von der Industrie gelieferten Konzentration, das Anti-CRP-Serum ${ }^{3}$ ) in Verdünnungen von 1:8 und 1:16 mit physiol. NaCl-Lösung verwendet. Dic Zeit bis zur optimalen Ausbildung der Präzipitationslinien betrug bei $37^{\circ} \mathrm{zwischen} 12$ und $36 \mathrm{Stdn}$. Die Dokumentation erfolgte durch Färbung der Präzipitationslinien mit Amidoschwarz $10 \mathrm{~B}$ und Photographie im durchscheinenden Licht.

Lipoproteidfärbung (in 1. c. (23))

Die mit den optimal auspräzipitierten. Antigen-Antikörper-Systemen ausgestatteten Objektträger-Präparate wurden für 12 Stdn. in 1proz. NaCl-Lösung gelegt. Es wurde hierfür eine MehrzweckKüvette (24) verwendet, die ein müheloses Wechseln der Lösung in etwa 2 stdg. Abständen gestattet, ohne daß die Agarschicht vom Objektträger abschwimmen kann. Danach wurden ObjektträgerPräparate unter Filtrierpapier bei 37 bis $40^{\circ}$ getrocknet, das Filtrierpapier durch leichtes Befeuchten mit dest. Wasser entfernt und nunmehr in eine Sudanschwarz B-Färbelösung gelegt.

\section{Sudanschbyarz B-Färbelösung}

1proz. Sudanschwarz B-Lösung in 60proz. Äthanol. Mehrmals filtrieren. Färbezeit $30 \mathrm{Min}$.

\section{Entfärben}

$3 \mathrm{mal}$ je $15 \mathrm{Min}$. in 50proz. Äthanol. Ptäparat lufttrocknen.

Doksmentation erfolgt durch Photographieren im durchscheinenden Licht. il

\section{Ergebnisse}

Die Befunde nach zweidimensionaler Immuno-Doppeldiffusion im Agargel geben eindeutig zu erkennen, daß das C-reaktive Protein mit keiner der hier gegenübergestellten Serumkomponente eine immunologische Iden-

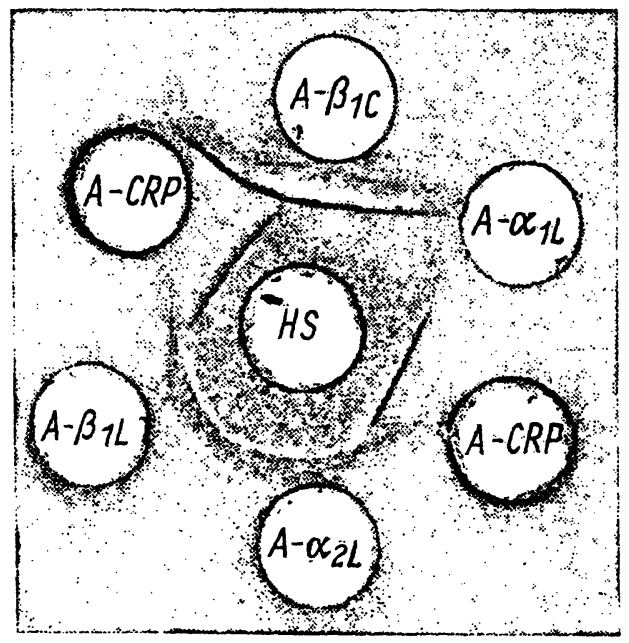

Abb. 2

Befunde der zweidimensionalen Immuno-Doppeldiffusion im Agargel bei vergleichender Versuchsanordnung. Verglichen wurden $C$-reaktives Protein (CRP) mit $\alpha_{1}$-Lipoproteid $\left(\alpha_{1 L}\right)$, C-reaktives Protein mit $\alpha_{2}$-Lipoproteid $\left(\alpha_{2 L}\right)$, C-reaktives Protein mit $\beta_{1}$-Lipoproteid $\left(\beta_{1 L}\right)$ sowie C-reaktives Protein mit $\beta_{1}$-Globulin $\left(\beta_{1}\right.$ C) $\mathrm{HS}=$ Humanserum; A- $=$ Anti-

3) Sämtliche Antiseren wurden von den Behringwerken, Marburg/ Lahn bezogen. titätsreaktion aufweist. Es ergaben sich auch keine Hinweise für nur partielle Identität (Abb. 2). Dies gilt sowohl für die normal beschaffenen als auch für die stark lipämischen Seren.

Nach Behandlung der Immunodiffusions-Präparate mit Sudanschwarz B fand sich eine deutliche Färbung der spezifischen Immunpräzipitate ifür die $\alpha_{1}-, \alpha_{2}-$ und $\beta_{1^{-}}$ Lipoproteidfraktionen, nicht aber der Präzipitate des $\beta_{1 \mathrm{c}}$-Globulins und des C-reaktiven Proteins.

Zwischen dem Präzipitat des $\alpha_{2}$-Lipoproteids und dem des $\beta_{1}$-Lipoproteids ließ sich sowohl mit der Amidoschwarz- als auch mit der Sudanschwarz-Färbung und selbstverständlich auch unter den Nativpräzipitaten eine immunologische Identitätsreaktion nachweisen.

\section{Diskussion}

Die Ergebnisse beweisen, daß C-reaktives Protein und Lipoproteide eines menschlichen Serums sowie Creaktives Protein und $\beta_{1 \mathrm{C}}$-Protein keine immunchemisch faßbare Antigengemeinschaft besitzen. Die eingangs zitierte, in der Literatur immer wieder beschriebene enge Bindung von $\mathrm{C}$-reaktivem Protein an Phosphorlipoide (14, 17-19) ist deshalb entweder als reines Anlagerungsphänomen oder als biochemische Reaktion zwischen C-reaktivem Protein und Lipoiden ohne Proteinanteil zu verstehen.

Die Identitätsreaktion zwischen $\alpha_{2}$-Lipoproteid und $\beta_{1}$-Lipoproteid entspricht einer hinlänglich bekannten Erfahrungstatsache aus der Protein-Immunchemie.

Die Befunde nach Färbung mit Sudanschwarz B lassen den Schluß zu, daß das C-reaktive Protein selbst offenbar kein Lipoproteid darstellt. Physikochemische Analysen weisen in der Tat auch darauf hin, daß gereinigtes C-reaktives Protein weder Lipidanteile noch Phosphor enthält (13, in 1. c. 18), dagegen Neuraminsäureester besitzt und die Fähigkeit, mit Mucopolysacchariden Komplexe zu bilden (25-27).

Mit Bezug auf das Verhalten des C-reaktiven Proteins zur $\beta_{1 \mathrm{c}}$-Globulinfraktion darf aufgrund der vorliegenden Befunde zwat die antigene Eigenständigkeit jedes der verglichenen Proteinsysteme als sicher gelten, es kann jedoch aus dem Ergebnis dieser Versuchsanordnung nicht ohne weiteres auf Reaktionsmechanismen hinsichtlich eines Komplementverbrauches beim Ablauf einer spezifischen CRP-Anti-CRP-Reaktion geschlossen werden.

Die Tatsache, daß sich das $\beta_{1 \mathrm{c}}$-Protein nicht mit Sudanschwarz B anfärben ließ, wird durch die Aufklärungsarbeit von MülLER-EBERHARD (28) dadurch bestätigt, $\mathrm{da} \beta_{1 \mathrm{C}}$ als Glykoproteid mit einem Kohlenhydratanteil von $3 \%$ ohne Lipidkomponente dargestellt werden konnte.

\section{Literatur}

1. Anzat, T., K. Sato, M. Fukuda und C. M. Carpenter, Proc. Soc. Exper. Biol. Med. N. Y. 120, 94 (1965). - 2. Bustamante, V., Bull. Soc. chim. biol. Paris, 39, 155 (1957). - 3. Bustamante, V., J. Arino und L. M. Y. Piniés, Presse méd., Paris 65, 313 (1957). -
4. Ferri, R. G. und W. Cossermerli, Arch. Internat. Rheumatol 1, 493 (1958). - 5. Götz, H., M. Pérez-Miranda und F. ScheifFARTH, diese Z. 7, 275 (1969). - 6. GörZ, H. und F. SChEIrFARTH, Newer findings about C-reactive protein, XVII. Coll. Prot. Biol. 
Fluids, Brügge (1969). - 7. HedLund, P. und I. BRATtSEN, a) Scand. J. Clin. Laborat. Invest. 7, 99 (1955); b) ibid. 8, 213 (1956). - 8. Herde, K., Bibl. Haematol. 12, 245 (1961). - 9. Heremans, J., Les globulines sériques du système gamma. Arscia S. A., Bruxelles u. Masson et Cie, Paris (1960). - 10. Mürler, W., N. KLEINE und M. Matries, Zschr. Rheumaforsch. 17, 226 (1958). - 11. Riley, R. F., M. K. Coleman und Y. Hokama, Clin. Chim. Acta (Amsterdam) 11, 530 (1965). - 12. Scheiffarth, F. und H. Götz, in Henning, H.: Praktische Ergebnisse neuer klinischer Forschung, Schattauer, Stuttgart (1962). - 13. Schultze H. E., G. Schwick, J. SonNET, J. Heremans und J. L. Michaux, Klin. Wschr. 38, 62 (1960). - 14. Wood, H. F., M. McCArtY und R. J. Slater, J. Exper. Med. 100, 71 (1954). - 15. ZACH, J. und K. ZIMMERMANN, Klin. Wschr. 37, 160 (1959). - 16. KeItel, W., Med. Klin. 57, 1925 (1962). - 17. MCCARTY, M., J. Exper. Med.
85, 491 (1947). - 18. Schwarz, G., Das C-reaktive Protein. Fortschr. d. Immunit.forsch. 5, Steinkopf, Darmstadt (1963). 19. Werner, B., Med. Mschr., Stuttgart 19, 303 (1965). - 20. Musine, L. H. und R. J. Weatherwax, Proc. Soc. Exper. Biol. Med. N. Y. 87, 191 (1954). - 21. RApport, M. M. und L. Graf, Proc. Soc. Exper. Biol. Med. N. Y. 93, 69 (1956). - 22. Ouchterzony, O., Progr. Allergy, 5, 1 (1958). - 23. Henning, N., Klinische Laboratoriumsdiagnostik, 3. Auf., Urban u. Schwarzenberg, München/Berlin/Wien (1966). - 24. PÉrez-Miranda, M. und H. Görz, diese Z. 6, 499 (1968). - 25. Hokama, Y., a) J. Immunol. Baltimoore 98, 521 (1967); b) ibid. 98, 529 (1967). 26. HoкAma, Y., M. K. Coleman und R. F. Riley, J. Immunol., Baltimoore 85, 72 (1960). - 27. RILEY, F. R. und Y. HoKAMA, Science Washington 132, 1894 (1960). - 28. MüllER-EberHARD, H. J., Acta Soc. med. Upsal. 66, 152 (1961).

Priv.-Doz. Dr. Hilde Götz 1 Berlin 19

Spandauer Damm 130 